DOI 10.31558/2519-2949.2021.4.5

УДК 321:061.2(477)

ORCID ID: https://orcid.org/0000-0003-4051-2484

Матвійчук А. В., Національна бібліотека Украӥни імені В. І. Вернадського

\title{
КАТЕГОРІЯ «САМОВРЯДНІ ОРГАНІЗАЦЇ̈ У ПОНЯТІЙНІЙ СИСТЕМІ ПОЛІТИЧНОЇ НАУКИ
}

У громадянському суспільстві особисті інічіативи є головним фактором у досягненні загального блага, і такі ініціативи найчастіше та найефективніше реалізуються через сукупність самоврядних організачій.

На відміну від політичних партій, самоврядні організачії не прагнуть досягти контролю над держсавною владою, а намагаються лише вплинути на владні структури і проиес прийняття рішень, які виражали б інтереси різних соиіальних верств населення. За умов ефективного функиіонування самоврядних організаиій уможливлюється адекватне відображення інтересів різних соиіально-демографічних груп, їх вихід у легітимний правовий простір, підвищення рівня політичної культури, рівноваги та стабільності суспільства, впорядкованості сочіальних інновацій і практичних дій його членів.

Самоврядні організаиії на сучасному етапі розвитку перебирають на себе дедалі більщий обсяг завдань, насамперед в соиіальній сфері, які раніше виконували лише органи державної влади. Тендениії розвитку самоврядних організацій показують, щь вони якісніше спроможні надавати суспільні послуги, ефективніше використовувати матеріальні та інші ресурси суспільства. Самоврядні організачії мають більшу довіру і допомогу з боку громадян, які, будучи залучені до певної ініціативи з боку самоврядної організачії, відчувають свою причетність до вирімення громадських суспільно важливих справ, що, у свою чергу, сприяє розвитку громадянського суспільства.

Самоврядні організаиій в громадянському суспільстві повинні бути важливим компонентом співпраці з державним й недержавним секторами для ефективного вирімення різнорідних проблем суспільства. Взаємодія між самоврядними організаџіями має базуватися не на конкурениії, а на партнерстві, співпрачі та взаємодопомозі.

Ключові слова: громадянське суспільство, громадські об'єднання, самоврядні організачії, самоврядування

Постановка проблеми. Однією з найхарактерніших рис громадянського суспільства $€$ існування певної верстви організованих людей, груп, осередків громадськості, які можуть концентрувати свої зусилля і відстоювати спільні інтереси перед державою. Тільки суспільство, де існує достатній масив різноспрямованих самоврядних об'єднань, можна вважати громадянським, адже взаємовідносини та взаємодія між державою й громадянським суспільством визначаються насамперед наявністю механізмів цієї взаємодії, якими є самоврядні організації.

Дослідження специфіки самоврядних організацій у понятійній системі політичної науки набирає ваги у зв'язку з тим, що у сучасному світі самоврядні організації дедалі посилюють стратегічну функцію як суб'єкта політики і важливого елемента становлення громадянського суспільства та саме від характеру та зростання (кількісного і якісного) самоврядних організацій значною мірою залежатимуть шляхи подальшого розвитку й українського суспільства.

Аналіз останніх досліджень. Роль громадянського суспільства упроцесі функціонування самоврядних організацій досліджували: Б. Венглярчик, К. Кандагура, Л. Кормич, М. Менджул, Х. Мепарішвілі, Е. Тоффлер, М. Ховард, В. Новохацький, Д. Шелест та ін.

Проблеми функціонування самоврядних організацій у контексті демократизації суспільства досліджували: В. Андрущенко, Ю. Бех, М. Братковський, Н. Гаєва, В. Дрешпак, В. Смельянов, В. Новак, С. Серьогін, В. Купрій, Д. Сірик, О. Штирьов та ін.

Проблематику взаємовідносин громадянського суспільства і держави досліджували: Г. Берченко, Є. Бистрицький, О. Бородій, В. Волков, Л. Герасіна, О. Головащенко, А. Гросс, О. Дем'яненко, О. Задоянчук, Дж. Кін, І. Кресіна, А. Колодій, О. Крюков, Д. Лейн, І. Макарова, Я. Пасько, П. Ситник, М. Шевченко та ін. 
Мета статті - розкрити специфіку, класифікацію та функціонал категорії «самоврядні організації» у понятійній системі політичної науки.

Виклад основного матеріалу. Активність громадянського суспільства проявляється у формі самоврядних організацій, які $€$ одним із найефективніших механізмів лобіювання інтересів у суспільстві. Самоврядні організації у повсякденному розумінні- це суб'єкти, незалежні від державної і місцевої адміністрації, які спрямовують свою діяльність на задоволення «суспільних потреб і переслідують гуманітарні цілі». Самоврядними організаціями є суб'єкти, які не входять в державну або місцеву економічну систему та не функціонують 3 метою отримання прибутку; юридичні особи, створені на основі розпоряджень, законів, у тому числі фонди та об'єднання, за винятком політичних партій, професійних спілок і організацій роботодавців, самоврядувань професій, фондів, єдиним засновником яких є Держскарбниця. Самоврядні організації, зазвичай, функціонують як фонди і об'єднання. Сфера і форми їхньої діяльності дуже різні. Найчастіше вони опікуються такими питаннями як культура, екологія, громадянські права, наука і техніка, моніторинг інформаційного простору і політичний аналіз тощо. Ключовими ознаками самоврядних організацій $\epsilon$ добровільність, незалежність, неприбутковість, суспільна корисність [1].

К. Меркулова визначає самоврядну організацію як «недержавне, добровільне об'єднання громадян, об'єднаних спільною метою щодо реалізації і захисту прав, а також соціальних, економічних, творчих, вікових, національно-культурних, спортивних та інших спільних інтересів, що здійснює вплив на суспільно-політичне життя та не ставить за основну мету свого існування отримання прибутку» [2, с. 8]. О. Юлдашев запропонував нове визначення самоврядних організацій, назвавши їх недержавними, а саме як «об'єднання, що утворюється громадянами України відповідно до Конституції на добровільній основі з метою задоволення і захисту своїх законних соціальних інтересів (досягнення легітимних цілей), діє прозоро і відкрито, у якого отримання прибутку від своєї діяльності не $\epsilon$ головною метою, а засобом для виконання власних статутних цілей» [3, с. 3].

Діяльність самоврядних організацій спрямована на подолання кризових явищ у суспільстві, збереження національних традицій, які сьогодні формують величезний потенціал культури та мобілізують нову інтелектуальну еліту нації. Від дієвості функціонування подібних інституцій залежить «моральне здоров'я» нації, стан іiі духовності, культурна самоідентифікація і самовідтворення. Водночас ефективність діяльності самоврядних організацій безпосередньо пов'язана 3 тим, яким чином відбувається взаємодія і співпраця інститутів громадянського суспільства 3 органами державної влади. Адже саме співробітництво і партнерство посилює потенціал та ресурсні можливості реалізації державної політики й вирішення важливих для суспільства проблем [4, с. 2].

Термін «самоврядна організація» можна зустріти в більшості правових систем у регіоні діяльності ОБСЄ, його використання в універсальних та регіональних стандартах застосовується щодо широкого кола різних інституційних форм (асоціації, спілки, благодійні організації, фонди, некомерційні корпорації, товариства і трести). Однак це більше їх фактична природа, а не офіційне призначення. Головне, щоб вони володіли певними ознаками або критеріями, що дають право їх так називати [5]. Ці ознаки розроблені Рекомендаціями Комітету міністрів держав-членів Ради Свропи про правовий статус самоврядних організацій в Свропі: «1. Для цілей цієї рекомендації неурядові громадські організації являють собою добровільні самоврядні об'єднання або організації, створені для здійснення некомерційних завдань їхніх засновників або членів. В їх число не входять політичні партії. 2. Неурядові громадські організації включають об’єднання або організації, створені як окремими особами (фізичними або юридичними), так і групами таких осіб» [6].

Таким чином, окреслення таких об’єднань як «громадських» або «близько до адміністративних» не повинно перешкоджати розглядати їх як самоврядні організації, що є точним відображенням їхніх основних характеристик. Поняття «об’єднання», «асоціація», «організація» тощо, по суті, означають те саме і позначають будь-яку групу фізичних і / або юридичних осіб, які зібралися разом для того, щоб колективно діяти і виражати, просувати, здійснювати або захищати спільні інтереси в певній сфері. Таке об'єднання є необхідним для людини, оскільки вона не завжди може сама вчиняти зазначені дії та досягати мети. Щодо значення права на свободу об'єднання, то воно захищає право створювати і вступати в групи однодумців та переслідувати спільні інтереси [7].

У загальному розумінні самоврядні організації мають наступну класифікацію: благодійні, національні, культурні, молодіжні, правозахисні, профспілкові, наукові, спортивні, професійні асоціації, організації, що представляють інтереси певної галузі промисловості або надають соціальні послуги та ін. [8, с. 10-11]. 
С. Лисенков серед основних критеріїв класифікації самоврядних організацій виділяє критерії членства, правового статусу, масштабів та обсягів діяльності:

- за умовами членства (організації з формально фіксованим та формально нефіксованим членством);

- за кількістю членів (масові та елітарні організації);

- за способом формування і ступенем охоплення мас (стихійні та свідомо організовані організації);

- за внутрішньою структурою (централізовані, нецентралізовані організації);

- за масштабом діяльності (місцеві, що поширюються на відповідні адміністративнотериторіальні одиниці; загальнодержавні, що діють на всій території держави та міжнародні, діяльність яких поширюється на територію держави-засновниці і хоча б ще однієї іноземної держави);

- за соціально-правовим статусом (легальні, нелегальні організації);

- за способом досягнення мети (реформаторські, консервативні організаціі);

- за соціальною значущістю для існування і розвитку суспільства (прогресивні, консервативні, реакційні організації) [9, с. 49].

В. Кравчук наводить класифікацію самоврядних організацій відповідно до сфери діяльності таких організацій:

1) права людини;

2) професійна діяльність;

3) поліпшення соціально-економічного становища країни;

4) сім'я та діти;

5) захист здоров'я населення та навколишнього середовища;

6) освіта;

7) культура [10, с. 87].

Детальніше розкриває таку класифікацію самоврядних організацій І. Лойко, називаючи іï при цьому класифікацією за критерієм спрямованості:

- професійні (профспілки, асоціації фермерів);

- економічні (об'єднання підприємців, банкірів, роботодавців);

- конфесійні (церкви, релігійні общини, об’єднання мирян);

- культурологічні та просвітницькі;

- творчі (об’єднання артистів, письменників, художників);

- спортивно-туристські та оздоровчі;

- наукові та науково-технічні;

- оборонні;

- національно-культурні;

- екологічні [11, с. 165].

Таким чином, самоврядні організації можуть виступати як активний суб'єкт соціальноекономічної і політичної дії (добровільне прийняття відповідальності за надання послуги або надання «суспільного блага» і його ефективність). Самоврядні організації із міжнародним статусом є одними із ключових суб' єктів такої дії, що відіграють вагому роль у процесах формування громадянського суспільства і правової держави, його демократизації, налагодження постійної взаємодії та співпраці між суспільством і державою тощо [12, с. 64]. Діяльність самоврядних організацій є одним з чинників становлення сучасного громадянського суспільства і водночас громадянське суспільство втілюється в різні самоврядні об'єднання, проходячи шлях від ідеї, взаємодії політичної культури та громадської волі до реально функціонуючого об'єднання [12, с. 66].

А. Шадрикова виділяє кілька форм прийняття рішень, а відповідно, і можливостей впливу сучасних самоврядних організацій: письмові звернення до органів влади, залучення засобів масової інформації, участь в законодавчих ініціативах, спроби або домовленості щодо проведення громадської експертизи, ініціатива організацій маршів протесту і демонстрацій, лобіювання через апарат органів влади, особисті зв'язки з особами, які відповідають за прийняття рішення тощо [13, с. 528].

Відповідно до вищезазначеного, до основних функції самоврядних організацій можна віднести: забезпечення ефективного посередництва між інтересами та потребами суспільства і владою (інтегративна функція); оцінювання діяльності органів державної влади та місцевого самоврядування, відстеження наслідків таких рішень для населення; швидке реагування на потреби населення [12, с. 89]. 
Важливим $є$ виконання самоврядними організаціями інтегративної функції, яка охоплює процеси консолідації, поєднання зусиль, взаємозалежності, комформності особистих цілей індивідів 3 цілями інших або цілями всієї групи і взаємовідповідальності членів соціальних груп, що відбуваються на підставі інституціональних норм, правил поведінки. Такі інтегративні процеси $\epsilon$ не тільки необхідними для всього суспільства (раціоналізуючи і публічно представляючи інтереси різних верств і соціальних груп, самоврядні організації сприяють знаходженню консенсусу між ними та нормативного його закріплення державними органами, тим самим забезпечують інтеграцію суспільства), але й становлять одну з важливих умов виживання самої організації (згуртування людей всередині організації підвищує іiї стійкість, цілісність і $є$ способом узгодження цілей ії учасників). Крім вищезазначеного, самоврядні організації сприяють зміцненню комунікативних зв'язків, надають можливість проявляти себе, доволі ефективно виконують функцію інформування (зокрема стосовно проблем, які не завжди $є$ на поверхні), допомагають адаптації політичної системи суспільства до нових умов діяльності, результативно інституціоналізують соціальні норми, правила, статуси, приводять їх в систему, що здатна діяти у напрямку задоволення певної соціальної потреби. Частині самоврядних організацій властива інструментальна функція, яка полягає у виборі методів реалізації практичних завдань [10, с. 79-80].

При встановленні обмежень щодо діяльності самоврядних організацій ключове значення має суспільний інтерес, - фактор втручання держави у діяльність самоврядних організацій, що охоплює різні аспекти: національну безпеку, збереження та забезпечення безпечного існування расового, національного, релігійного різноманіття у суспільстві тощо [12, с. 148].

А. Ткачук визначає суспільний інтерес як такий, що прямо протилежний інтересу приватному, та діє заради задоволення інтересів своїх членів або організації взаємодопомоги. Відповідно до суспільно корисних організацій відносяться такі організації, які працюють для суспільства в цілому - через їхнє сприяння благодійництву, розвитку освіти, науки, культури, захисту природного середовища, надання певних соціальних послуг тощо [14, с. 5].

До таких організацій А. Бодров відносить: організації «взаємодопомоги», котрі об'єднують людей за принципом спільної біди або проблеми; соціально спрямовані (благодійні фонди та організації, орієнтовані на вирішення гуманітарно-соціальних проблем); організації «клубного типу», що включають різноманітні групи самовдосконалення, клуби за інтересами; «суспільноохоронні», які зосереджені на захисті навколишнього середовища в широкому сенсі, тобто діяльності з охорони не лише природи, але й культури, мови тощо; правозахисні організації; «інфраструктурні» неурядові організації, чия місія - сприяння діяльності інших самоврядних організацій в найширшому сенсі [15, с. 54].

Умовою функціонування соціально відповідальних самоврядних організацій мають стати державні органи, які забезпечать участь організацій у повному циклі реалізації державної політики у сфері виконання соціальних специфічних програм - від самого початку, тобто від їх створення до реалізації окремого конкретного розділу та пункту [16, с. 456].

Роль самоврядних організацій в соціальній політиці країн Європейського Союзу, де існує практика залучення всіх зацікавлених сторін до визначення пріоритетних соціальних проблем у соціальній сфері та пошуку ефективних методів для їх вирішення, уже стала визначальною, тобто участь самоврядних організацій у формуванні цієї політики - абсолютно необхідна [17].

Таким чином, в залежності від політичної спрямованості держави, самоврядні організації можуть відігравати різні ролі, а саме: 1) об'єднання, що представляють соціальних рух; 2) організації, які виступають як групи тиску; 3) міжнародні самоврядні об'єднання; 4) суспільно корисні організації; 5) самоврядні організації, які несуть інформаційне або пропагандистське навантаження [12, с. 197-198].

Порівнюючи формування і діяльність самоврядних організацій в Україні та інших європейських країнах можна виокремити такі основні відмінності:

1) фінансування діяльності організацій: діяльність європейських організацій значною мірою фінансується урядом, бізнесовими структурами, членськими внесками, благодійними внесками, а діяльність українських самоврядних організацій фінансується у більшості випадків донорськими програмами зарубіжних країн, державне ж фінансування та внески організацій чи громадян $€$ незначними;

2) проєкти українських самоврядних організацій, зазвичай, не є довготермінові;

3) діяльність українських самоврядних організацій в основному спрямована на вирішення актуальних соціальних проблем і зорієнтована на проведення проєктів тільки на національному й регіональному рівнях; 
4) для досягнення своєї мети самоврядні організації в Україні, у більшості випадків, здійснюють заходи в одному обраному напрямку, тоді як європейським організаціям характерні поліваріантні шляхи досягнення своєї мети, тобто здійснення різноманітних заходів у декількох напрямках;

5) головна особливість - недосконалість правового забезпечення і регламентації формування та функціонування самоврядних організацій в Україні порівняно з європейськими країнами [10, с. 81].

Для ефективного виконання проєктів, фінансованих з державного бюджету, самоврядна організація повинна детально аналізувати не тільки свої потреби, а й державні, а також поєднувати інтереси обох сторін у складанні відповідних проєктів [18, с. 241]. I. Ткачук пропонує розглядати державне фінансування самоврядних організації як можливість, а не право останніх. При цьому, щоб уникнути негативного впливу такого фінансування, а також подолати корупційні схеми, необ'єктивну вибірковість та неефективність співпраці, дослідник пропонує впровадити принципи європейської практики, які зберігають незалежність громадського сектора від державного та слугують підтримці здорового балансу між ними. Орієнтація державного фінансування на потреби громадян тут визнається одним із основних принципів розподілу державних коштів [19, с. 221].

Перспективними напрямками взаємодії самоврядних організацій з органами державної влади можуть бути наступні напрямки:

- поширення соціальних цінностей громадянського спрямування (громадянська гідність, потреба в постійному спілкуванні, отриманні постійної інформації про стан справ, довіра між людьми, схильність цінувати і проявляти солідарність тощо);

- вирішення виникаючих спорів та конфліктів на основі взаємного поважання думок, консенсусу;

- обмін думками по актуальним питанням розвитку держави та суспільства;

- участь у соціальній і волонтерській діяльності;

- проведення роботи по підвищенню культури та вихованню громадськості;

- поширення інформації про основну мету й задачі розвитку громадянського суспільства;

- підвищення рівня інформованості членів громади щодо діяльності органів державної влади та місцевого самоврядування;

- підтримка місцевих ініціатив [17, с. 43-44].

Отже, рівень гарантованості права на об'єднання є визначальним показником політичного та соціального положення країни. Відповідно основним призначенням самоврядних організацій $\epsilon$ агрегування, артикуляція та подальше лобіювання інтересів соціальних груп. Самоврядні організації дають можливість суспільству користуватися перевагами демократичної системи, яка дає змогу кожному висловлювати та відстоювати свою думку й погляди. Через самоврядні організації громадяни мають можливість впливати на рівень розвитку суспільства, утворювати ефективну противагу посиленню зловживань з боку держави, протидіяти авторитаристським та радикальним настроям у суспільстві, цим самим беручи на себе частину відповідальності за загальний стан справ у державі.

\section{Бібліографічний список:}

1. Законодавче регулювання діяльності неприбуткових організацій: світовий досвід та рекомендації для України. URL: https://parlament.org.ua/2001/10/01/broshura-zakonodavche-regulyuvannya-ngo/ (дата звернення: 23.06.2021).

2. Меркулова К. О. Адміністративно-правове регулювання діяльності громадських організацій: автореф. дис. к. ю. н.: 12.00.07. Ірпінь, 2014. 20 с.

3. Юлдашев О. О. Адміністративно-правове забезпечення діяльності недержавних громадських організацій в Україні: автореф. дис. к. ю. н.: 12.00.07. Київ, 2013. 19 с.

4. Гололобов С. М. Розвиток механізмів взаємодії громадських організацій у сфері культури з органами публічної влади України: автореф. дис. к. держ. упр.: 25.00.02. Чорноморський національний університет імені Петра Могили. Миколаїв, 2020. 25 с.

5. Чернявська Б. Значення неурядових (громадських) організацій як показника рівня демократії та розвитку громадянського суспільства у державі.

URL: https://journals.indexcopernicus.com/api/file/viewByFileId/907944.pdf (дата звернення: 24.06.2021).

6. Рекомендації Комітету міністрів Ради Свропи державам-членам стосовно правового статусу неурядових організацій у Європі. Офіційний веб-сайт Верховної Ради України.

URL: http://zakon2.rada.gov.ua/laws/show/994_937 (дата звернення: 23.06.2021).

7. Федулов С., Гнездилова О. Международные стандарты в сфере свободы ассоциаций.

URL: http://library.khpg.org/files/docs/1398690048.pdf (дата звернення: 23.06.2021).

8. Лейкі, Беріт М. Врядування неприбуткових організацій: підзвітність та повноваження - головні принципи врядування: Пер. з англ. К.: Вид. дім «КМ Академія», 2003. 56 с. 
9. Лисенков С. Л. Загальна теорія держави і права: навчальний посібник. К.: «Юрисконсульт», 2006. 355 с.

10. Кравчук В. М. Взаємовідносини громадських організацій і держави в умовах формування громадянського суспільства в Україні (теоретико-правові аспекти): дис. к. ю. н.: 12.00.01. Київський національний університет внутрішніх справ. К., 2008. 229 с.

11. Лойко Л. І. Громадські організації етнічних меншин України: природа, легітимність, діяльність: монографія. К.: Фоліант, 2005. 634 с.

12. Дорофеєва В. І. Конституційні засади участі громадських об'єднань у системі захисту прав людини: Україна та зарубіжний досвід: дис. к. ю. н.: 12.00.02. Ужгородський національний університет. Ужгород, 2018. $232 \mathrm{c}$.

13. Шадрикова А. П. Некоммерческие организации: роль и влияние в процессе принятия политических решений. Модернизация экономики и глобализация: в 3 кн. Москва: Издательский дом ГУ-ВШЭ, 2009. Кн. 1. C. $527-534$.

14. Ткачук А. Ф. Законодавство для третього сектору: необхідність та перспектива змін. К.: Ін-т громадянського суспільства, 2002. 32 с.

15. Бодров А. В. Класифікація неурядових організацій в сучасній науковій літературі. Наукові праці МАУП. 2014. ВиП. 1. С. 53-57.

16. Дементов В. О. Громадські організації в Україні: вплив на прийняття соціально-відповідальних рішень. Теорія та практика державного управління. 2010. Вип. 4. С. 452-457.

17. Петрушенко Ю. М. Місцевий розвиток за участі громади: монографія: у 2 т. Т. 2: Інституційні та прикладні аспекти управління місцевим розвитком, орієнтованим на громаду.

URL: https://essuir.sumdu.edu.ua/bitstream-download/123456789/50480/7/Petrushenko_mistsevyi_rozvytok.pdf (дата звернення: 25.06.2021).

18. Сосєдова В. С. Державне фінансування діяльності громадських організацій в Україні. Актуальні проблеми економіки. 2009. № 8. С. 238-241.

19. Ткачук І. Я. Впровадження європейських принципів державного фінансування українськими громадськими організаціями. Вісник Одеського національного університету. Серія: «Економіка». 2014. Т. 19, вип. 2 (5). С. 219-223.

\section{References:}

1. Zakonodavche rehuliuvannia diialnosti neprybutkovykh orhanizatsii: svitovyi dosvid ta rekomendatsii dlia Ukrainy. URL: https://parlament.org.ua/2001/10/01/broshura-zakonodavche-regulyuvannya-ngo/ (data zvernennia: 23.06.2021).

2. Merkulova K. O. Administratyvno-pravove rehuliuvannia diialnosti hromadskykh orhanizatsii: avtoref. dys. k. yu. n.: 12.00.07. Irpin, 2014. $20 \mathrm{~s}$.

3. Iuldashev O. O. Administratyvno-pravove zabezpechennia diialnosti nederzhavnykh hromadskykh orhanizatsii v Ukraini: avtoref. dys. k. yu. n.: 12.00.07. Kyiv, 2013. 19 c.

4. Hololobov S. M. Rozvytok mekhanizmiv vzaiemodii hromadskykh orhanizatsii u sferi kultury z orhanamy publichnoi vlady Ukrainy: avtoref. dys. k. derzh. upr.: 25.00.02. Chornomorskyi natsionalnyi universytet imeni Petra Mohyly. Mykolaiv, 2020. 25 s.

5. Cherniavska B. Znachennia neuriadovykh (hromadskykh) orhanizatsii yak pokaznyka rivnia demokratii ta rozvytku hromadianskoho suspilstva u derzhavi.

URL: https://journals.indexcopernicus.com/api/file/viewByFileId/907944.pdf (data zvernennia: 24.06.2021).

6. Rekomendatsii Komitetu ministriv Rady Yevropy derzhavam-chlenam stosovno pravovoho statusu neuriadovykh orhanizatsii u Yevropi. Ofitsiinyi veb-sait Verkhovnoi Rady Ukrainy.

URL: http://zakon2.rada.gov.ua/laws/show/994_937 (data zvernennia: 23.06.2021).

7. Fedulov S., Hnezdylova O. Mezhdunarodnые standartы v sfere svobodы assotsyatsyi.

URL: http://library.khpg.org/files/docs/1398690048.pdf (data zvernennia: 23.06.2021).

8. Leiki, Berit M. Vriaduvannia neprybutkovykh orhanizatsii: pidzvitnist ta povnovazhennia - holovni pryntsypy vriaduvannia: Per. z anhl. K.: Vyd. dim «KM Akademiia», 2003. 56 s.

9. Lysenkov S. L. Zahalna teoriia derzhavy i prava: navchalnyi posibnyk. K.: «Iuryskonsult», 2006. $355 \mathrm{~s}$.

10. Kravchuk V. M. Vzaiemovidnosyny hromadskykh orhanizatsii i derzhavy v umovakh formuvannia hromadianskoho suspilstva v Ukraini (teoretyko-pravovi aspekty): dys. k. yu. n.: 12.00.01. Kyivskyi natsionalnyi universytet vnutrishnikh sprav. K., 2008. 229 s.

11. Loiko L. I. Hromadski orhanizatsii etnichnykh menshyn Ukrainy: pryroda, lehitymnist, diialnist: monohrafiia. K.: Foliant, 2005. 634 s.

12. Dorofeieva V. I. Konstytutsiini zasady uchasti hromadskykh obiednan u systemi zakhystu prav liudyny: Ukraina ta zarubizhnyi dosvid: dys. k. yu. n.: 12.00.02. Uzhhorodskyi natsionalnyi universytet. Uzhhorod, $2018.232 \mathrm{~s}$.

13. Shadrykova A. P. Nekommercheskye orhanyzatsyy: rol y vlyianye v protsesse pryniatyia polytycheskykh reshenyi. Modernyzatsyia эkonomyky y hlobalyzatsyia: v 3 kn. Moskva: Yzdatelskyi dom HU-VShЭ, 2009. Kn. 1. S. 527-534.

14. Tkachuk A. F. Zakonodavstvo dlia tretoho sektoru: neobkhidnist ta perspektyva zmin.

K.: In-t hromadianskoho suspilstva, 2002. $32 \mathrm{~s}$. 
15. Bodrov A. V. Klasyfikatsiia neuriadovykh orhanizatsii v suchasnii naukovii literaturi. Naukovi pratsi MAUP. 2014. Vyp. 1. S. 53-57.

16. Dementov V. O. Hromadski orhanizatsii v Ukraini: vplyv na pryiniattia sotsialno-vidpovidalnykh rishen. Teoriia ta praktyka derzhavnoho upravlinnia. 2010. Vyp. 4. S. 452-457.

17. Petrushenko Yu. M. Mistsevyi rozvytok za uchasti hromady: monohrafiia: u 2 t. T. 2: Instytutsiini ta prykladni aspekty upravlinnia mistsevym rozvytkom, oriientovanym na hromadu.

URL: https://essuir.sumdu.edu.ua/bitstream-download/123456789/50480/7/Petrushenko_mistsevyi_rozvytok.pdf (data zvernennia: 25.06.2021).

18. Sosiedova V. S. Derzhavne finansuvannia diialnosti hromadskykh orhanizatsii v Ukraini. Aktualni problemy ekonomiky. 2009. № 8. S. 238-241.

19. Tkachuk I. Ya. Vprovadzhennia yevropeiskykh pryntsypiv derzhavnoho finansuvannia ukrainskymy hromadskymy orhanizatsiiamy. Visnyk Odeskoho natsionalnoho universytetu. Seriia: «Ekonomika». 2014. T. 19, vyp. 2 (5). S. 219-223.

Matviichuk A. V. Category "Self-governing organizations» in the concept system of political science

In civil society, personal initiative is a major factor in achieving the common good, and such initiatives are often and effectively implemented through a collection of self-governing organizations.

Unlike political parties, self-governing organizations do not seek to achieve control over state power, but only try to influence power structures and the decision-making process that would express the interests of various social strata of the population. In the conditions of the effective functioning of self-governing organizations, it becomes possible to adequately reflect the interests of various socio-demographic groups, their exit to a legitimate legal space, an increase in the level of political culture, balance and stability of society, the orderliness of social innovations and practical actions of its members.

Self-governing organizations at the present stage of development are taking on an increasing volume of tasks, primarily in the social sphere, which were previously performed only by state authorities. The development trends of self-governing organizations show that they are better able to provide public services, more efficiently use the material and other resources of society. Self-governing organizations have greater confidence and assistance from citizens, who, being involved in certain initiatives from a selfgoverning organization, feel their involvement in solving public socially important issues, which, in turn, contributes to the development of civil society.

Self-governing organizations in civil society should be an important component of cooperation with the state and non-state sectors to effectively address the diverse problems of society. Interaction between self-governing organizations should not be based on competition, but on partnership, cooperation and mutual assistance.

Keywords: civil society, public associations, self-governing organizations, self-government. 